\title{
Penyuluhan Dampak Kebakaran Hutan Dan Lahan Terhadap Penyakit Saluran Pernafasan Pada Lansia
}

\author{
Ervi Audina Mumthe dan Anna Marthea Veronicha \\ Program Studi Pendidikan Dokter, Fakultas Kedokteran UPR \\ e-mail: eamunthe@med.upr.ac.id
}

\begin{abstract}
Abstrak
Kebakaran hutan yang tidak terkendali menimbulkan kabut asap dalam jumlah yang sangat besar dan membahayakan kesehatan. Tingginya kadar indeks standar pencemaran udara (ISPU) di beberapa wilayah Kota Palangka Raya, dapat menjadi ancaman serius bagi kesehatan. ${ }^{1}$ Melihat kejadian tersebut maka sebagai wujud implementasi Tri Dharma Perguruan Tinggi, sehingga sebagai dosen mengambil peran aktif dalam program pengabdian masyarakat dengan dilakukanlah penyuluhan untuk pencegahan dan penanggulangan dari penyakit saluran pernafasan yang disebabkan kebakaran hutan dan lahan. Target dalam pelaksanaan pengabdian masyarakat ini adalah Posyandu Lansia Bina Sehat di PKM Kalampangan.Luaran kegiatan ini yang terutama yaitu adanya peningkatan pengetahuan dan kesadaran dengan indikator luaran besar peningkatan dalam skor.Metode yang digunakan adalah metode pendidikan masyarakat dengan ceramah penyuluhan dan praktik, Kesimpulan dari program pengabdian ini masyarakat sudah memiliki pengetahuan tentang kejadian karhutla terhadap penyakit saluran pernafasan kegiatan penyuluhan dengan tingkat pengetahuan responden Kurang (60\%), Cukup (10\%), dan Baik (30\%). Selain itu, diadakan pemeriksaan kesehatan gratis dengan lansia sangat antusias dengan didapatkan yang mengalami Hipertensi sebanyak 9 orang, Hiperkolesterolemia sebanyak 4 orang, dan Hiperurisemia sebanyak 6 orang.
\end{abstract}

Kata kunci : kebakaran hutan, kabut asap, lansia, penyuluhan, pemeriksaan

\section{Pendahuluan}

Kebakaran hutan yang tidak terkendali menimbulkan kabut asap dalam jumlah yang sangat besar dan membahayakan kesehatan. Tingginya kadar indeks standar pencemaran udara (ISPU) di beberapa wilayah Kota Palangka Raya, dapat menjadi ancaman serius bagi kesehatan. ISPU adalah laporan kualitas udara kepada masyarakat untuk menerangkan seberapa bersih atau tercemarnya kualitas udara dan dampaknya terhadap kesehatan kita setelah menghirup udara tersebut selama beberapa jam atau hari. $^{1}$

Secara umum kabut asap dapat mengganggu kesehatan seseorang. Gangguan kesehatan yang dapat timbul jika terpapar lama dengan asap, antara lain: 1) Iritasi lokal, reaksi alergi; 2) Iritasi pada mata dan kulit; 3) memperburuk asma dan penyakit paru kronis lain, seperti bronkitis kronik; 4) Mudah terjadi infeksi misalnya infeksi saluran pernapasan akut (ISPA); 5) Berbagai penyakit kronik dapat memburuk.
Ini terjadi karena dampak langsung maupun dampak tidak langsung yang mana kabut asap menurunkan daya tahan tubuh atau menimbulkan stress. ${ }^{1}$

Melihat kejadian tersebut maka sebagai wujud implementasi Tri Dharma Perguruan Tinggi, sehingga sebagai dosen mengambil peran aktif dalam program pengabdian masyarakat dengan dilakukanlah penyuluhan untuk pencegahan dan penanggulangan dari penyakit saluran pernafasan yang disebabkan kebakaran hutan dan lahan.

Konsep program kemitraan masyarakat stimulus (PKMS) adalah penyuluhan akan diwujudkan dalam penyusunan materi penyuluhan dan pemaparannya serta dilakukan pemeriksaan gratis untuk lansia di wilayah kerja posyandu lansia. Pusat Kesehatan Masyarakat yang dijadikan mitra oleh pengusul dalam Program Kemitraan Masyarakat Stimulus (PKMS) adalah PKM Kalampangan.PKM ini berlokasi Jalan Mahir Mahar Gg. Mawar, Kel. 
Kalampangan Kec. Sabangau, Kota Palangka Raya, Kalimantan Tengah.

\section{Metode Pelaksanaan}

Adapun metode pelaksanaan kegiatan ini menggunakan metode ceramah dan praktik. Tahapannya adalah sebagai berikut :

a. Tahap Persiapan

Pada tahap ini tim pengusul melakukan observasi terhadap masyarakat lansi. Hal ini dilakukan untuk mengetahui kondisi Posyandu Lansia PKM Kalampangan dan masalah yang dialami.

Pada tahap ini juga tim pengusul menyiapkan materi dalam bentuk Microsoft Power point, leafleat dan xbanner.

b. Tahap Pelaksanaan

Pada tahap ini dilakukan pemberian soal Pre - test dan Post - test untuk mengukur pengetahuan peserta, penyuluhan yaitu pemaparan materi secara terstruktur diikuti dengan sesi Tanya - jawab kemudian dilakukan pemeriksaan gratis dan pembagian masker.

c. Tahap Pemeriksaan Gratis

Pada tahap pelaksanaan kegiatan pemeriksaan dan pengobatan gratis adalah registrasi kemudian anamnesis, pemeriksaan dan pemeriksaan tekanan darah (Tekanan Darah : Sistole $=90-$ $120 \mathrm{mmHg}$, Diastole $=60-80 \mathrm{mmHg}$ ) dilanjutkan pemeriksaan darah berupa pemeriksaan kadar asam urat (Asam urat Pria: 3,4 - 7,0 mg/dl, Perempuan: 2,4 $5,7 \mathrm{mg} / \mathrm{dl})$ dan pemeriksaan kadar kolesterol (Kolesterol total $<200 \mathrm{mg} / \mathrm{dl}$ ) kemudian pemeriksaan lanjutan oleh Dokter dan pemberian obat serta edukasi kesehatan.

d. Tahap Evaluasi

Pada tahap ini dilakukan evaluasi terhadap peserta yaitu untuk melihat hasil dari penyuluhan dan juga dilakukan evaluasi terhadap tahap tahap kegiatan yang telah dilakukan.

\section{Hasil Dan Pembahasan}

\section{Gambaran Umum Khalayak Sasaran}

Data yang diperoleh meliputi data umum responden yaitu berdasarkan jenis kelamin, umur, pekerjaan, dan tingkat pendidikan. Data khusus menampilkan tingkat pengetahuan peserta Posyandu Lansia Bina Sehat di PKM Kalampangan setelah melalui kegiatan pengabdian ini.

Berdasarkan Tabel 1dibawah ini menunjukkan bahwa lansia yang hadir mayoritas berjenis kelamin perempuan sebesar $90 \%$.

Tabel 1. Distribusi Frekuensi Responden Berdasarkan Jenis Kelamin

\begin{tabular}{|c|c|c|c|}
\hline $\begin{array}{l}\text { No } \\
\text {. }\end{array}$ & $\begin{array}{l}\text { Jenis } \\
\text { Kelamin }\end{array}$ & Frekuensi & $\%$ \\
\hline 1 & Laki - laki & 2 & 10 \\
\hline 2 & Perempuan & 18 & 90 \\
\hline Tot & & 20 & 100 \\
\hline
\end{tabular}

Berdasarkan Tabel 2 dibawah sebagian besar responden paling banyak berusia 46 - 55 tahun(40\%) dan paling sedikit berusia $56-65$ tahun (25\%). 
Tabel 2. Distribusi Frekuensi Responden Berdasarkan Umur.

\begin{tabular}{llcc}
\hline No. & $\begin{array}{l}\text { Umur } \\
\text { (Tahun) }\end{array}$ & Frekuensi & $\%$ \\
\hline 1 & $\begin{array}{l}\text { Lansia awal } \\
(46-55)\end{array}$ & 8 & 40 \\
2 & $\begin{array}{l}\text { Lansia akhir } \\
(56-65)\end{array}$ & 5 & 25 \\
3 & $\begin{array}{l}\text { Manula } \\
(>65)\end{array}$ & 7 & 35 \\
\hline \multicolumn{2}{l}{ Total } & 20 & 100 \\
\hline
\end{tabular}

Tabel 3. Distribusi Frekuensi Responden Berdasarkan Pekerjaan

\begin{tabular}{|c|c|c|c|}
\hline No. & Pekerjaan & Frekuensi & $\%$ \\
\hline 1 & $\begin{array}{l}\text { Ibu Rumah } \\
\text { Tangga }\end{array}$ & 11 & 55 \\
\hline 2 & Wiraswasta & 4 & 20 \\
\hline 3 & Petani & 5 & 25 \\
\hline Total & & 20 & 100 \\
\hline
\end{tabular}

Berdasarkan Tabel 3 di atas sebagian besar responden memiliki pekerjaan sebagai Ibu Rumah Tangga (55\%), Wiraswasta (20\%), dan Petani (25\%).

Tabel 4. Distribusi Frekuensi Responden Berdasarkan Tingkat Pendidikan

\begin{tabular}{llll}
\hline No. & \multirow{2}{*}{ Pendidikan } & Frekuensi & \% \\
\hline 1 & SD & 5 & 25 \\
2 & SMP & 7 & 35 \\
3 & SMA & 8 & 40 \\
\hline \multicolumn{2}{l}{ Total } & 20 & 100 \\
\hline
\end{tabular}

Berdasarkan Tabel 4 sebagian besar responden memiliki pendidikan lulusan SD (25\%), lulusan SMP (35\%), dan lulusan SMA (40\%).

Melihat dari kondisi dilapangan khalayak sasaran masih belum memahami dampak pada kabut asap akibat karhutla dan pencegahan yang dapat dilakukan oleh tiap individu. Oleh karena itu diberikan pemahaman tentang pencegahan dan penanggulangan dari penyakit saluran pernafasan yang disebabkan karhutla, guna mencegah keparahan pada khalayak masyarakat.

\section{Data Khusus Tingkat Ketercapaian Sasaran Program}

1. Tingkat Pengetahuan

Adapun pada tahap pelaksanaan kegiatan pengabdian ini dilakukan Pretest dan Post - test sebelum dan sesudah melakukan penyuluhan. Menurut Arikunto, membuat kategori tingkat pengetahuan seseorang menjadi tiga tingkatan yang didasarkan pada nilai persentase yaitu sebagai berikut. $^{2}$
a. Tingkat pengetahuan kategori Baik jika nilainya $\geq 76-100 \%$.
b. Tingkat pengetahuan kategori Cukup jika nilainya $60-75 \%$.
c. Tingkat pengetahuan kategori Kurang jika nilainya $\leq 60 \%$.

Tabel 5. Distribusi Frekuensi Responden Berdasarkan Tingkat Pengetahuan

\begin{tabular}{llllll}
\hline No. & Kategori & Tingkat & Pre - test & & \multicolumn{2}{c}{ Post - test } \\
& Pengetahuan & Nilai & $\%$ & Nilai & $\%$ \\
\hline 1 & Baik $(\geq 76-100 \%)$ & 0 & 0 & 6 & 30 \\
2 & Cukup $(60-75 \%)$ & 0 & 0 & 2 & 10 \\
3 & Kurang $(\leq 60 \%)$ & 20 & 100 & 12 & 60 \\
\hline Total & & 20 & 100 & 20 & 100 \\
\hline
\end{tabular}




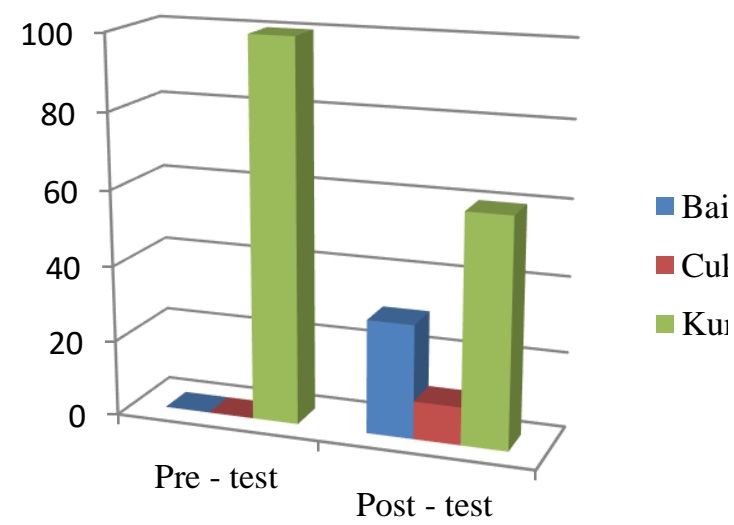

Gambar1.Distribusi Frekuensi Responden Berdasarkan Tingkat Pengetahuan

Berdasarkan Tabel 5 dan Gambar 5 diatas didapatkan tingkat pengetahuan responden saat Pre - test paling banyak adalah tingkat pengetahuan Kurang (100\%) dan saat dilakukan Post - test setelah kegiatan penyuluhan didapatkan tingkat pengetahuan responden Kurang (60\%), Cukup (10\%), dan Baik (30\%).

Tingkat ketercapaian program dalam peningkatan pengetahuan khayalak sasaran dikatakan meningkat karena terdapat peningkatan dari kurang hingga terdapat yang cukup dan baik.

2. Hasil Pemeriksaan Tekanan Darah dan Pemeriksaan Darah

Tabel 6. Hasil Pemeriksaan Tekanan Darah dan Pemeriksaan Darah Pada 20 Peserta Lansia

\begin{tabular}{llc}
\hline No. & $\begin{array}{l}\text { Pemeriksaan TD dan } \\
\text { Darah }\end{array}$ & Frekuensi \\
\hline 1 & Hipertensi & 9 \\
2 & Hiperkolesterolemia & 4 \\
3 & Hiperurisemia & 6 \\
\hline
\end{tabular}

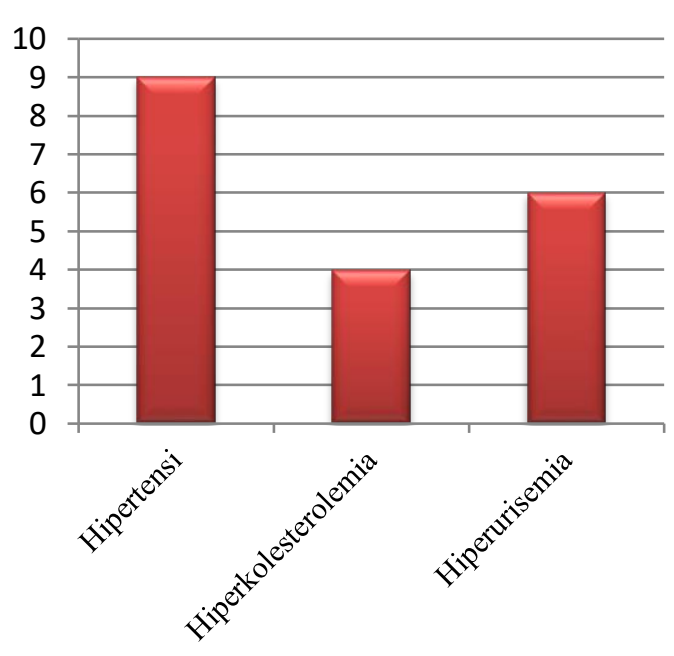

Gambar 2. Hasil Pemeriksaan Tekanan Darah dan Pemeriksaan Darah Pada 20 Peserta Lansia

Berdasarkan Tabel 6 dan Gambar 2 diatas dari pemeriksaan tekanan darah dan pemeriksaan darah yang dilakukan pada 20 peserta lansia didapatkan yang mengalami Hipertensi sebanyak 9 orang, Hiperkolesterolemia sebanyak 4 orang, dan Hiperurisemia sebanyak 6 orang.

\section{Kesimpulan Dan Saran}

Pelaksanaan kegiatan pengabdian masyarakat ini berjalan dengan lancar.Sebagian besar lansia yang hadir didominasi perempuan (90\%), lulusan SMA (40\%). Peserta yang mengikuti kegiatan ini paling banyak berusia $46-55$ tahun $(40 \%)$ dan paling sedikit berusia $56-$ 65 tahun (25\%).Peserta yang memiliki pekerjaan sebagai Ibu Rumah Tangga (55\%), Wiraswasta (20\%), dan Petani $(25 \%)$.

Tingkat pengetahuan peserta yang didapatkan pada saat Pre - test paling banyak tingkat pengetahuan Kurang (100\%) dan saat dilakukan Post - test setelah kegiatan penyuluhan didapatkan tingkat pengetahuan responden Kurang (60\%), Cukup (10\%), dan Baik (30\%). 
Hasil pemeriksaan tekanan darah dan pemeriksaan darah yang dilakukan pada 20 peserta lansia didapatkan yang mengalami Hipertensi sebanyak 9 orang, Hiperkolesterolemia sebanyak 4 orang, dan Hiperurisemia sebanyak 6 orang.

\section{Daftar Pustaka}

Arikunto, S. 2010. Prosedur Penelitian Suatu Pendekatan Praktik. Jakarta: Rineka Cipta.

Kementerian Kesehatan Republik Indonesia.(2015). Kemenkes Tanggapi Hasil Studi Kematian Akibat Karhutla.(Online). Diakses pada tanggal 6 September 2019, dari: https://depkes.go.id.

\section{Lampiran Foto Kegiatan}
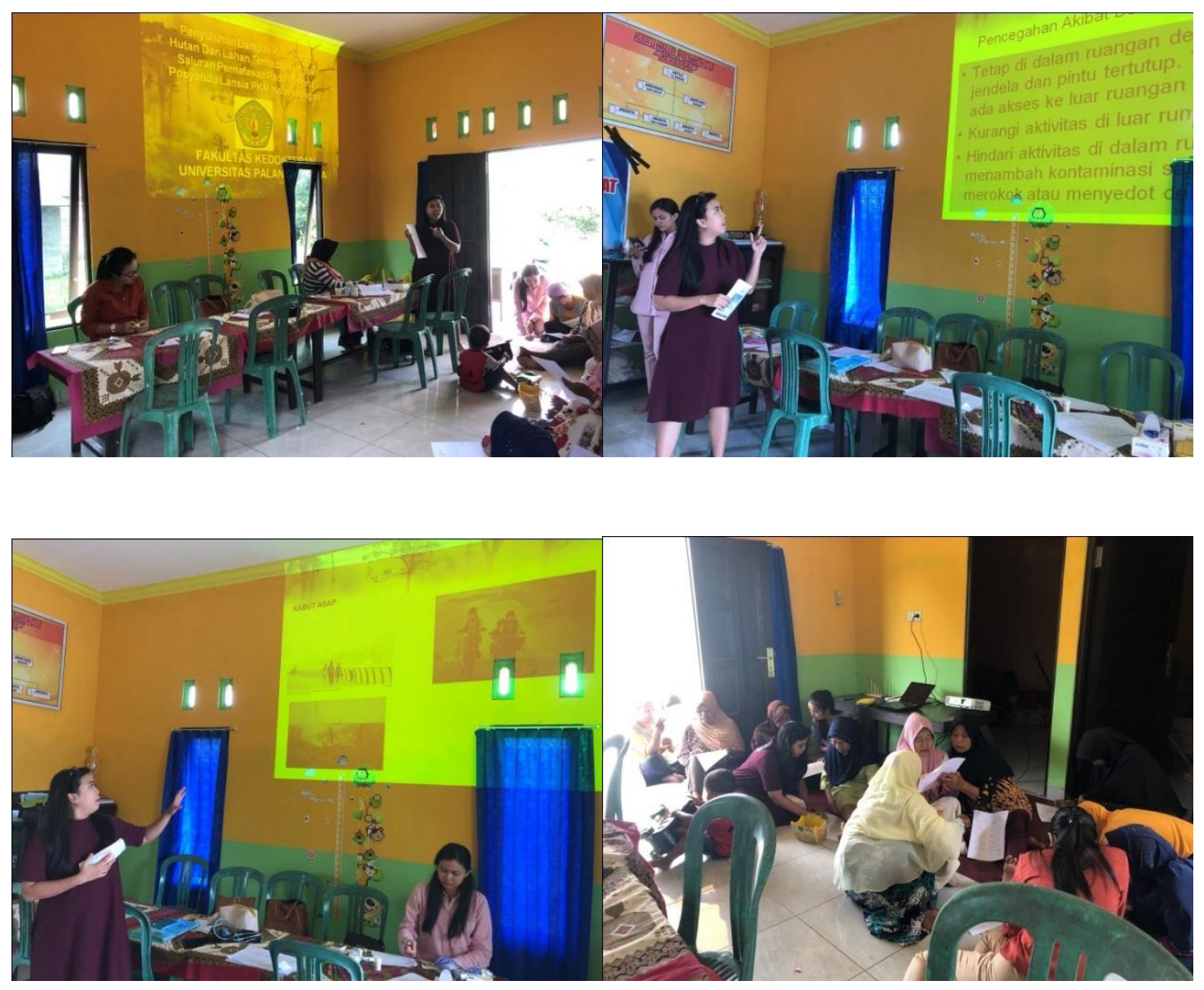
091X(e)

Vol 7. No.1, 17-22, July 2020
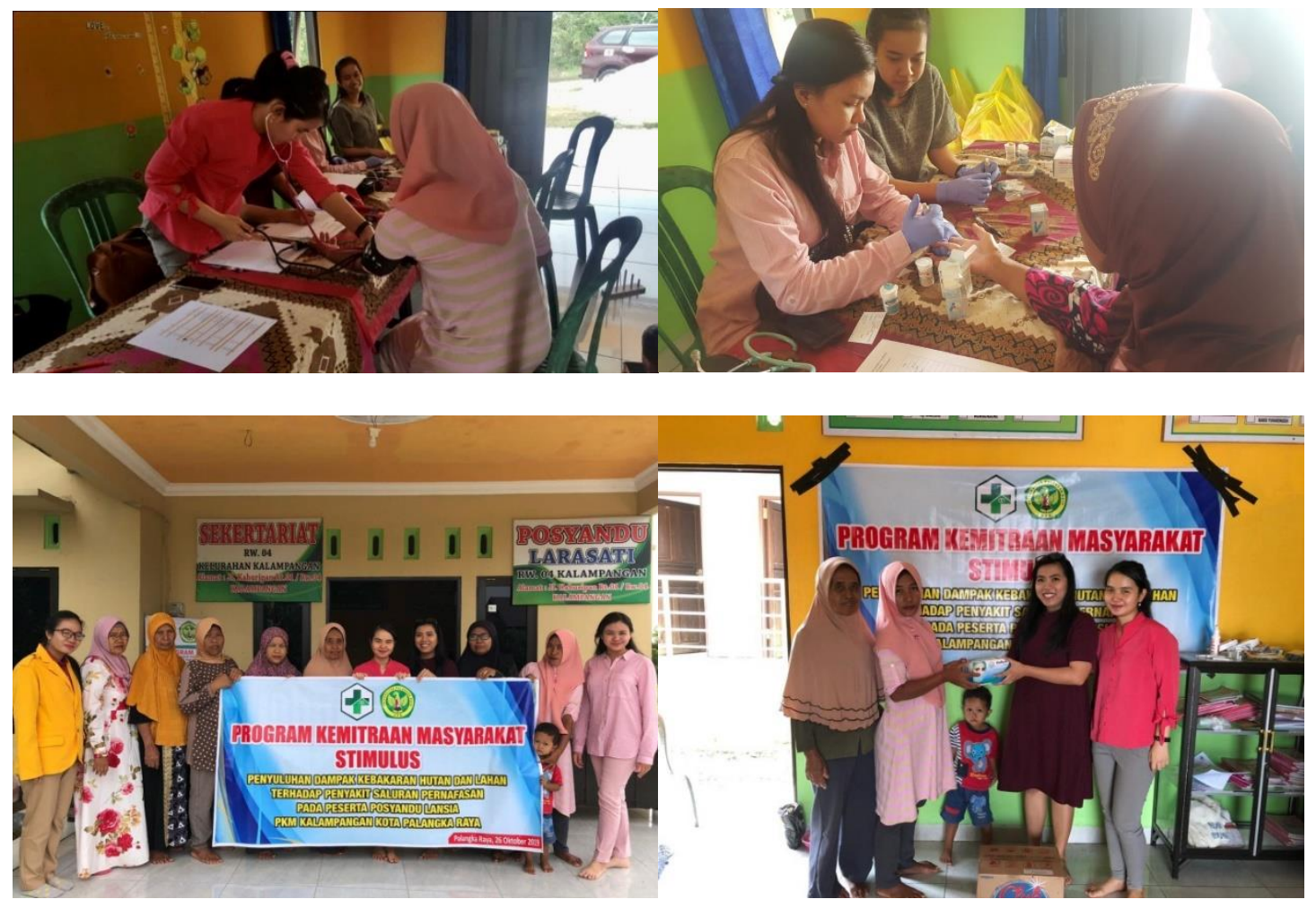